\title{
A Strategy for Research on Governing the Anthropocene
}

\author{
Rolfe A. Leary \\ Research Scientist (retired) \\ USDA Forest Service Research \\ Saint Paul, Minnesota \\ USA \\ raleary@,comcast.net
}

\author{
Vivian Kvist Johannsen \\ Senior Researcher \\ IGN, Forest, Nature and Biomass \\ University of Copenhagen \\ Denmark \\ vkj@ign.ku.dk
}

\begin{abstract}
We present a hierarchical triangular framework to guide anthropocene governing research. We lay out basic system levels and inter-relations. We include a 'human' level, and address the different affects human activities are exerting on the other levels and interrelations. We point out that in more recent times; man's affects have extended more deeply into the lowest levels of earths systems, such as atmosphere and energy. Since our objectives are to discover, organize, deliver and evaluate new knowledge to better govern the anthropocene, we look at simple cybernetic concepts of effector and feedback via controller. The chances of effective governance can be increased if the important source properties can be identified and their dynamics be used by the cybernetic controller - to lower the level of complexity encountered. Research in the anthropocene needs to ensure that research; from the experimental design, the data collection, the analyses and models; maintain an understanding of the triangle of systems, the interactions and the feedbacks to the systems. Only this way can research support the governance in the Anthropocene, based on environmental data, use of cutting edge research and understanding of the theory of systems.
\end{abstract}

Keywords-systems theory, modelling, environmental data, governance support, forests

\section{INTRODUCTION}

An increasing number of articles and researchers indicate a change in the Earth's state, indicating a new geological epoch named the Anthopocene; since environmental changes are driven by humans $[1,2,3]$. Whether the Earth formally is in a new epoch and regardless of when it started the current human activities, through uptake and output, impacts the environment at different scales. One of the outputs in focus during recent decades is the emissions of $\mathrm{CO}_{2}$ to the atmosphere. But, much more is going on under the influence of human activities. Developing mathematical models based on environmental information required to govern an extremely complex system -the "Anthropocene" -- presents many challenges.

\section{A GOVERNANCE CHALLENGE}

Society, including corporations, needs models for governance based on 'high quality' scientific research. However, doing 'high quality' scientific research that spans the required levels of reality, is significantly more complex than the more common narrowly focused single level research. Designing and conducting "controlled experiments", at the "size and time scales' required to provide reliable models for the current Anthropocene governance, is extremely expensive, hence susceptible to funding shortfall. At the same time, society wants 'explanatory'/'causal' models of Anthropocene dynamics. But, the inability to design and conduct controlled experiments will likely force scientists to accept doing descriptive models, sometimes cobbled together with disparate specialized data sources, with the result that their research will deliver singular descriptions rather than universal explanations [4].

The traditional 'systems' perspective, with identified systems of composition, structure, environment [5] is compromised, because in an earlier era a scientist could assign something to the 'environment' and be confident that, although it might fluctuate, it didn't warrant being moved into the system composition. In the Anthropocene, it seems every system component is in a state of change, hence requires being treated as a 'state variable' rather than a 'parameter of state $[6,7]$. Caution is in order, to identify and focus on the dynamics of source properties of systems [8].

\section{A SYSTEMS PERSPECTIVE}

We present a systems perspective of the Anthropocene based on triangular coordinates $[9,10]$ formed from intersections of levels, systems, and six orders of interaction indirectness. This is illustrated in Figure 1, where systems of reality (a) are given as follows: First Energy, then Atmosphere, then Terrestrial, Aquatic and Marine (TAM), then Microbes, then Plants, then Animals and Humans.

The levels of Indirectness the intra level interactions is indicated in (b).

The order of interaction is indicated by the third dimension (c). The full systems are formed by diagonals and combinations of all the perspectives - systems, levels and order of interaction (d).

The approach can subordinate populations of things (lots \& lots of them) to relationships between populations. There are only 9 qualitatively different relations, and just as populations of things have trajectories in a state space, interactions between populations may have trajectories in the interaction space [11]. 
In Figure 2, examples are given of different uses of the approach. One (a) is different groupings of subsystems using Russian ecologist's concept of "coenose". i.e. collection of life forms that are found together, interacting as a community within an ecosystem [12].

a) levels of reality



b) intra-level

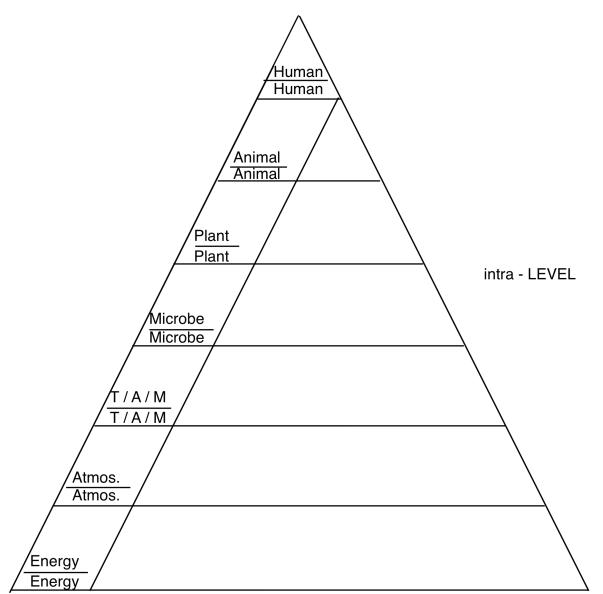

Figure 1. The progression from levels of reality, to intra-level interactions, to orders of interaction indirectness
Another use of the system is given in b) by grouping of subsystems in a project to re-introduce draft animals in Zambia, by the NGO Heifer International [13]. Problem began with termination of free veterinarian services following independence in 1964. Many draft animals died from diseases. After several decades many farmers had no experience with draft animals for field operations, so a broad approach touching on each subsystem was employed by Heifer with good effect. Finally, it is common practice to lump subsystems into what is called 'environment' and possibly higher and lower habitat that affect the subject cell - here plant-plant (c).

c) levels + order of interaction in triangular coordinates

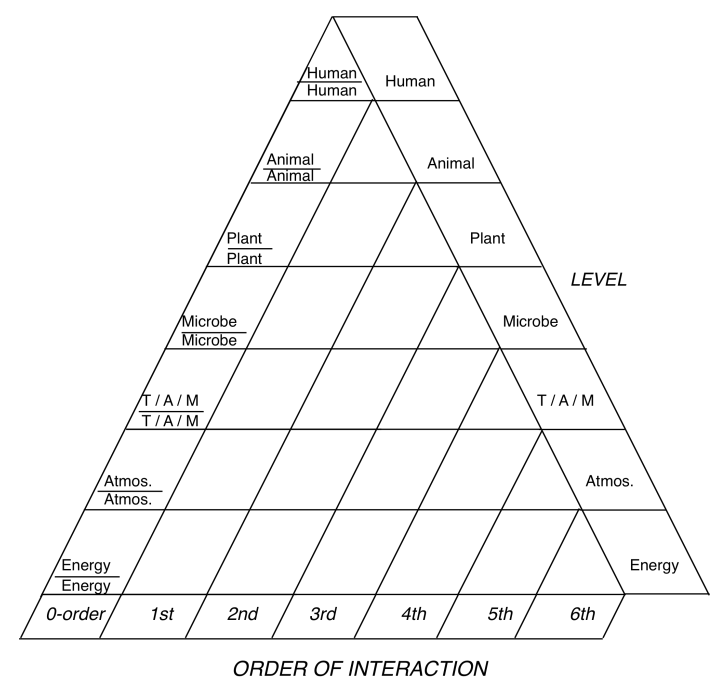

d) combination of levels, order of interaction, systems.

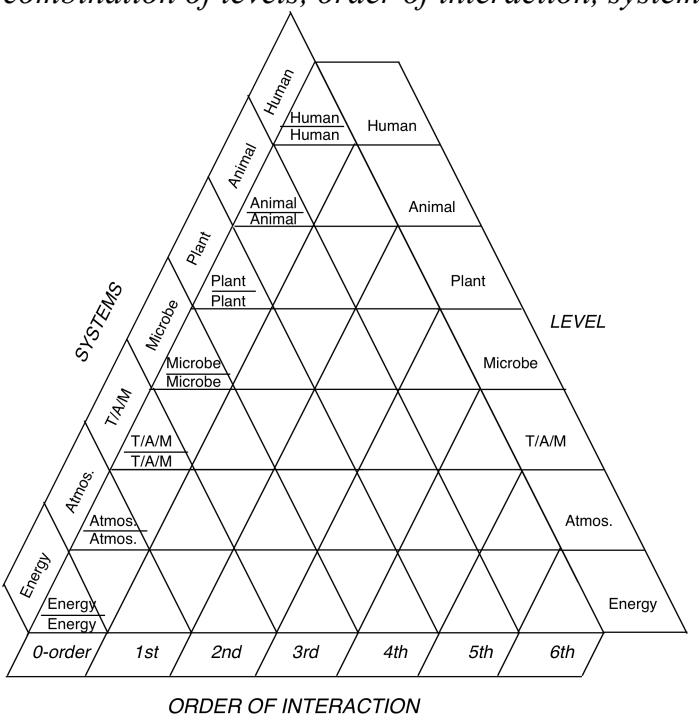




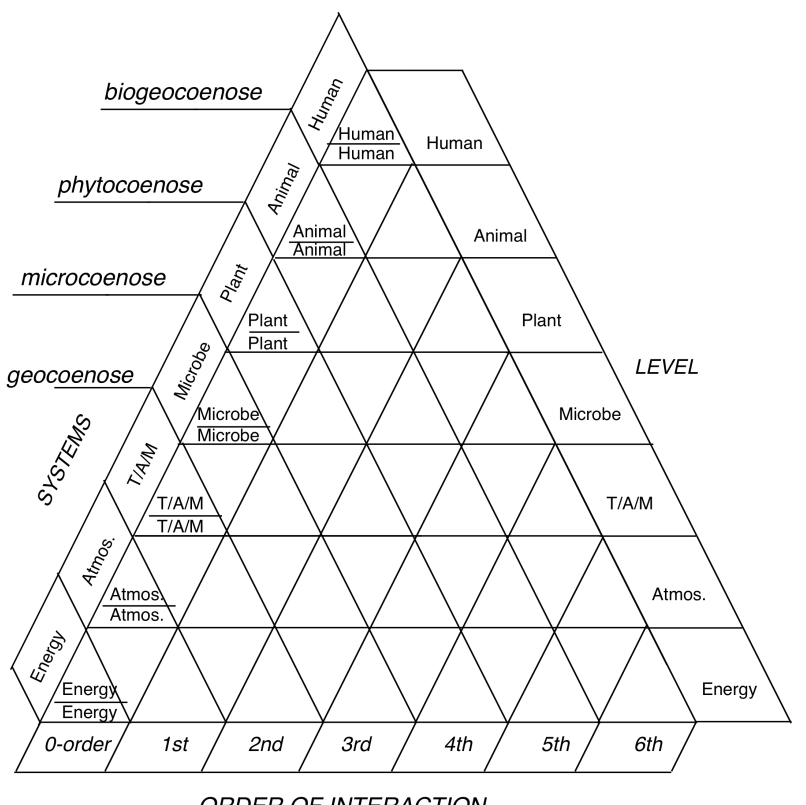

b)

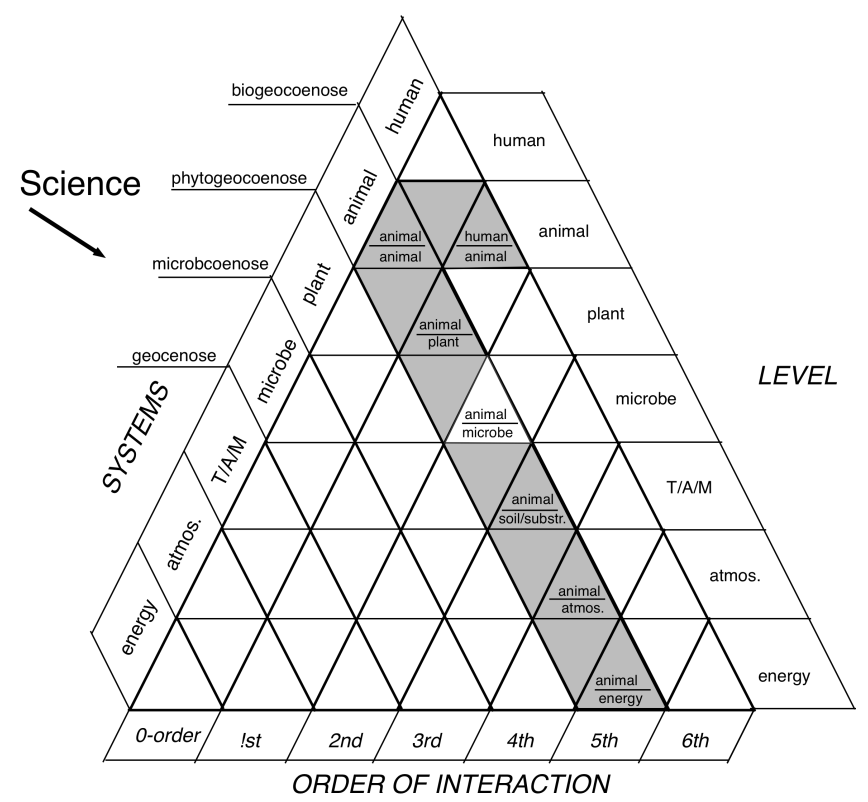

Figure 2. Examples of different uses of the system. a) Groupings using Russian ecologist's concept of "coenose". b) Draft animals in Zambia, c) Grouping focusing on'environment' and plant-plant interactions.

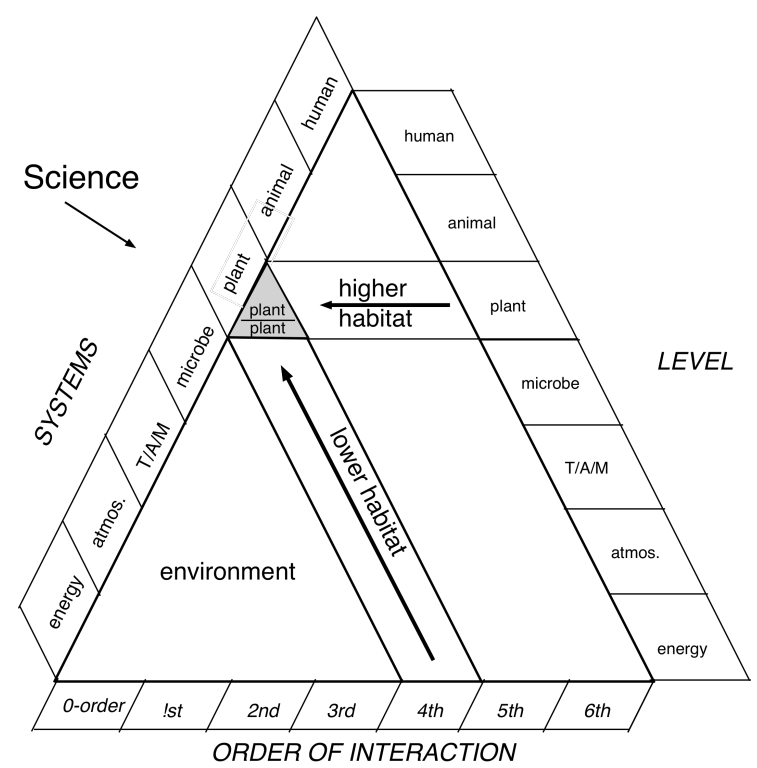

\section{HISTORICAL RESEARCH ON THE SYSTEMS}

Typically experiments and models have been conducted with a focus on the systems from the left side. As a classical example, forest growth models have been important tools in practical forestry during the last two centuries as well as in forest research. Initially, simple tabulations of growth were used, but at the end of the 18th century graphical descriptions were common. Gradually, mathematical descriptions of growth and statistical methods have gained dominance in development of growth models. So far a vast number of growth models have been developed and described, ranging from simple height-age curves to complex spatial, single tree models, including models for growth processes [14, 15].

The common denominator of these approaches is the approach to the systems from the left side of the triangle. Some of the first models for analysis of environmental impact on tree and forest growth were developed more than 100 years ago [e.g.16 - 26]. These are mainly monospecific forest stand dynamics, where the interactions modelled is of the 0-order focused on the plant-plant interactions, having soil and atmosphere constant, or at least varying within limits.

The perspective on a 1st order interaction can be given by the interactions of plant - insect dynamics, as e.g. the attacks by pine weevil on newly planted trees [27]. 


\section{The Anthropocene}



\section{ORDER OF INTERACTION}

Figure 3 Examples of different utilizations of the systems and their interactions [images 41-52].

Another example of plant-insect dynamics is given by Jönsson et al [28] on the interaction of Eurasian spruce bark beetle, Ips typographus, one of the major forest insect pests in Europe. This study includes atmospheric interactions, reflecting the emerging need for increasing complexity of the systems, but also noting that experimental knowledge is limited for some elements of the system modelled. Studies reported by KroëlDulay et al [29] include more systems, orders of interactions and levels.

The so-called FACE (Free Atmospheric Carbon Exchange) research study was an experimental treatment study centered on a $3^{\text {rd }}$ order interaction cell (plant-atmosphere). The purpose was to understand tree species response to elevated levels of $\mathrm{CO}_{2}$ and $\mathrm{O}_{3}$, and to test the interactive effects of carbon dioxide and ozone. Plants were forest tree species in a Northern Wisconsin USA ecosystem, and the study was a collaboration between U.S. Forest Service Research, U.S. Department of Energy, and Michigan Technological University. FACE-type studies, wherein treatments are applied to interior subsystems, are extremely expensive and tend to last only until outside funding is exhausted - 1998 to 2008 in this case. The FACE-type study could be contrasted with, say, plant-plant studies on the left side of triangle that focus on Bakuzis matrix properties -- which may be observed for several decades. A somewhat similar study has been conducted in Denmark by the Climaite project [e.g. 29], focusing on heathland vegetation.

The joint tendency of analyses and models indicate, that doing science in an era of the Anthropocene will be extremely challenging in several respects, requiring increasing complexity of experimental data and models. In recent decades it has become clear that energy and atmosphere systems are not constant, which was clearly noted in the 
1980 'es with the dieback and diseases of forests caused by pollution across multiple European forest areas.

\section{SIGNS OF THE ANTHROPOCENE IN THE SYSTEMS}

Interactions in the systems affect the long term development of the systems and their balances. This can be seen in dynamics in plant communities, as reported by Ransijn et al [30] for heathland vegetation. Humans interact with the systems, and sometimes the balance in the system is so influenced that it is pushed towards a negative state, of which some examples are indicated in Figure 3. Examples of this includes over exploitation of plants, with deforestation as one example in Europe during the period 1000-2000, and currently in many other parts of the world, leading to desertification and subsequent soil erosion. Other examples are depletion of populations of animals, through hunting or fishing beyond the carrying capacity of the system, or introducing species to new ecosystems, resulting in invasive behavior and effect on local ecosystems [31]. Man's affect have extended deeply into the lowest levels of earths systems, such as atmosphere and energy, where the source of human's power has moved from biomass, wind and water to fossil fuels for a long time, and only recently are tending to return to renewable energy sources. Even within the human system we have examples of negative interactions, e.g. wars and over population. Interactions between the human system and the microbe system may in some instances lead to a decline of the human system due to disease.

But, are humans a governor of the systems? And what could be expected from an ungoverned system? Does there need to be a controller? Controllers in mechanical feedback systems have been used for centuries.

Therefore, if experimental data and modelling of the systems are to provide support to governance in the current period, the Anthropocene, there is a need for methods to approach these questions.

\section{CONTROLLERS AND EFFECTORS IN A MULTILEVEL FRAMEWORK}

The Anthropocene is a giant system of feedback systems, as sketched above. This system of systems has outputs that humans, as the highest evolved life form, sense and try to make sense of. If their conclusion is one of dissatisfaction, they often engage in some form of actions to bring the outputs more in line with expectations/desires. Chances of success will be improved by developing an understanding of the systems and the feedback elements essential in support of governance. The governance of the Anthropocene can be modeled using concepts from cybernetics (Figure 4), wherein our triangular coordinate representation is functionally equivalent to a deLatil effector [32, 33], and where outputs from the Anthropocene can be sensed and fed back to the effector, through a system of controllers based on 4 categories of values used in decision making: economic (financial), ecosystem, societal, bioethical. Different ordering of decision making values will, over time, produce different Anthropocene outputs.

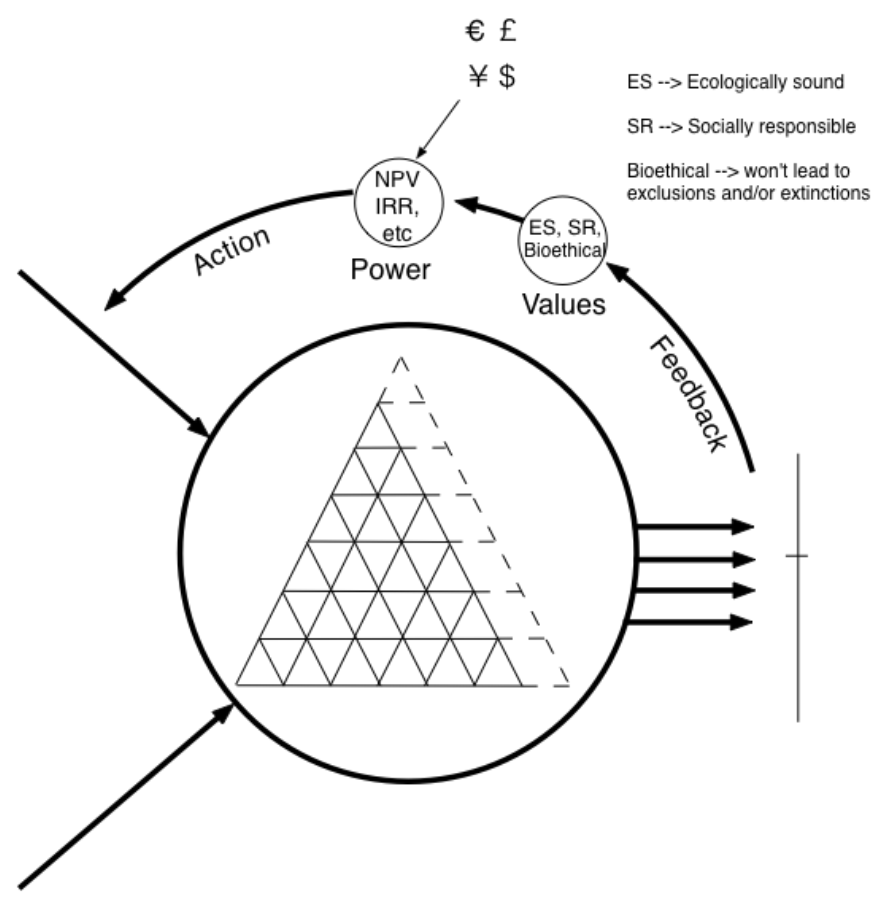

Figure 4. Governance of the Anthropocene in the context of a cybernetic system with feedback and different classes of 'controller' elements. [Based on 34]. Symbols: NPV - Net Present Value, IRR - Internal Rate of Return.

Predominant in the 'corporate' world is the use of controllers based on financial values. Every forestry undergraduate student has probably learned to compute Internal Rate of Return (IRR), Net Present Value (NPV), and other measures of forest financial performance. Some were taught the formulas to compute the present value of an infinite sum of periodic incomes from forest harvests in perpetuity. Such is the contrast between concerns of corporate officers trying to meet Wall Street expectations (expressed as next quarterly profits), and forest land managers (perpetuity). But there are other criteria the controller could use besides the financial.

The 'ecologic' controller is concerned with system health, constant/stable production of biomass, resilience, etc. It can be very effective if one is able to identify and makes system decisions based on a 'source property' e.g. nutrient cycling from leaf fall back into living matter in forests or recycling of woody ashes to the forests.

The 'societal' controller is concerned with the fellowman's wellbeing, especially opportunities for meaningful employment at reasonable wages in future generations. In this controller, perhaps a source property would be circulation of money in society. As opposed to siphoning and hoarding monies, as seems to be the current practice among some.

The 'bioethical' controller can be characterized as the concern for the 'created order' as some clergy might express it. Others would say it aims to guard against ecological (competitive) exclusions - because the last exclusion is extinction. This can 
be seen as one of the reasons behind legislation targeted at ensuring continuance of endangered species.

Numerous certification schemes for management of natural resources (e.g. FSC, PEFC, SBP) aims at sustainability measured by multiple categories of decision making, reflecting a concern not only for the present but also the future functioning of the systems.

\section{OPTIONS FOR GOVERNING THE ANTHROPOCENE}

Given that the Anthropocene is characterized by environmental changes being driven by human activities, and feedback is based on human choices, how can modeling of the systems support governance? What are the controllers that have led to the current situation, and which can get us out? One perspective is to choose the order of the controllers: ecological, societal, bioethical and financial, and their internal strengths.

An example of an ecological controller is applied where the areas are managed based on a well constrained balance of interaction type and intensity in nature. In the governance of the US National Forests as well as in the Danish State Forests, there are some felling's of trees, hunting is allowed, but at the same time some efforts are included to protect streams and water catchments, special habitats, indicating the inclusion of an ecological controller in the decision process, as also indicated by Larsen [35] on the development of the Close to Nature forest management in Denmark. Analysis and understanding of ecological controller are given by e.g. [36, 37].

An example from Menominee Indian Community in NE Wisconsin, USA (1850) gives priority to the societal controller [38]. The Menominee tribal elder reportedly said "think of the affects an action will have on the 7th generation of folks that follow you", given basis of the Indian nation idea of the "Seventh generation sustainability". Societal is in this setting a human-human relation not only instantaneous but also over generations of humans.

Another example would set bioethical as the first and dominating controller. This is based on the noting that more than $80 \%$ of the world's vegetables and fruits require a pollinator to produce. These pollinators include bats, butterflies, moths, flies, birds, beetles, ants and bees [39].

The financial controller build upon an array of options bioethical, societal and ecological - and then decide which among them is the most rewarding (to humans) financially, often time giving time discounting/interest rate to high a weight, resulting in a focus on the near future, rather than the long term development.

Are there ways to combine the different controllers? In some cases they are combined by a uniform controller - the financial, by means of assigning a financial value to the outputs and feedbacks of the different systems, with the risk of evaluating current and future benefits differently. Another approach lists a multitude of controllers, as presented by Ray et al [40], who present effects of forest management on a number of key systems and outputs.

\section{FUTURE RESEARCH IN GOVERNING THE ANTHROPOCENE}

So, how would this system guide research that will support governing of the Anthropocene? How can research support a long term sustainable development?

To return to the forests, the challenges of managing forest are to ensure that they are: 1) economically efficiency, 2) ecologically sound, 3) socially responsible, and 4) in bioethical balance.

This is very difficult to accomplish in an era of rapid population growth and subsequent use of forest resources, and simultaneously decreased funding for research. Especially research that requires longer time spans than the typical short term research projects of 3- 5 years. Research institutions are increasingly expected to produce better models, for more diverse clients/needs, at a faster pace, with fewer scientists, who are being paid less.

In other research areas the same challenges are valid, with the same challenges of ensuring sustainability, ranging from food production to manufacturing of high end electronic communication tools, taking the full processes of development, production, usage and reuse into account.

So, research in the Anthropocene needs to ensure that research; from the experimental design, the data collection, the analyses and models; maintains an understanding of the triangle of systems, the interactions and the feedbacks to the systems.

Only in this way can research support governance in the Anthropocene, based on data, use of cutting edge research and understanding of the theory of systems.

\section{REFERENCES}

[1] Crutzen, P. J. Geology of mankind. Nature 415, 23 (2002).

[2] Crutzen, P. J.\& Stoermer, E. F. The Anthropocene. IGBP Global Change Newsl. 41, 17-18 (2000).

[3] Lewis, Simon L. and Maslin, Mark A. Defining the Anthropocene. Nature 519 (2015)

[4] Leary, R. A. 1985. A Framework for Assessing and Rewarding a Scientist's Research Productivity. Scientometrics 7(1-2): 29-38.

[5] Bunge, Mario. 1979. Ontology II: A world of systems. Treatise on Basic Philosophy, Volume 4. D. reidel Publishing Co. Dordrecht Holland. 314 p.

[6] Lotka, A.J. 1925. Elements of Physical Biology. Baltimore, Williams \& Wilkins Company. 495 pp.

[7] Lotka, A.J. 1956. Elements of Mathematical Biology. Dover Publications, New York. 465 p.

[8] Bunge, Mario 1967. Foundations of Physics. Berlin-Heidelberg-New York: Springer-Verlag.

[9] Bakuzis, E. V. and Brown, R. M. 1962. Elements of model construction and the use of triangular models in forest research. Forest Science $8(2): 119-131$

[10] Leary, R.A. 1986. Structuring a coherent research program for Northern forests. $18^{\text {th }}$ IUFRO World Congress, Ljubljana Yougoslavia, September 7-21. 1986.

[11] Leary, R.A. 1985: Interaction tehory in forest ecology and management. Martinus Nijhoff/Dr W. Junk 219 pp.

[12] Sukachev, V. and Dylis, N. 1964. Fundamentals of forest biogeocoenology. (Translated by J.M. Maclennan). Oliver and Boyd, London. $672 \mathrm{pp}$. 
[13] NGO Heifer International: http://www.heifer.org/join-theconversation/blog/2011/june/zambia-project-receives-interaction-bestpractice-award.html

[14] Skovsgaard, J.P. 1988. En introduktion til forstlige vækstmodeller. Projekt Tyndingsfri drift. Arbejdsnotat Nr. 8. Skovbrugsinstituttet. Den Kgl. Veterinær- og Landbohøjskole. 79 pp.

[15] Vanclay, J.K. 1994. Modelling forest growth and yield: Applications to mixed tropical forests. $\mathrm{CAB}$ International, Wallingford, United Kingdom. 336 pp.

[16] Reventlow, C.D.F. 1879: Forslag til en forbedret Skovdrift, grundet paa Undersøgelser over Træernes Vegetation i Danmarks og Slesvigs Skove. P. Hauberg \& Co., Kjøbenhavn. X + 206 pp. English version: A Treatise on Forestry, published 1960 by the Society of Forest History, Hørsholm, Denmark

[17] Gram, J.P. 1879: Om Konstruktion af Normal-Tilvæxtoversigter, med særlig Hensyn til Iagttagelserne fra Odsherred (I). Tidsskrift for Skovbrug 3:207-270.

[18] MacKinney, A.L. \& L.E. Chaiken 1939. Volume, yield, and growth of loblolly pin in the mid-Atlantic coastal region. U.S. Forest Service, Appalachian Forest Expt. Sta. Tech. Note 33. 30 pp.

[19] Clutter, J.L. 1963. Compatible growth and yield models for loblolly pine. Forest Science 9:354-371.

[20] Burkhart, H.E. \& P.T. Sprinz 1984. Compatible cubic volume and basal area projection equations for thinned old-field loblolly pine plantations. Forest Science 30:86-93.

[21] García, O. 1983. A stochastic differential equation model for height growth of forest stands. Biometrics, 39:1059-1072.

[22] García, O. 1994. The state-space approach in growth modelling. Can. J. For. Res. 24:1894-1903.

[23] Vanclay, J.K. 1988. A stand growth model for cypress pine. In: Ek, A.K., S.R. Shifley \& T.E. Burk (eds.). Forest growth modelling and prediction. Proc. IUFRO Conf., 23-27 Aug. 1987, Minneapolis, MN. USDA Forest Service, Gen. Tech. Rep. NC-120. pp. 998-1005.

[24] Pretzsch, H. 1992. Konzeption und Konstruktion von Wuchsmodellen für Rein- und Mischbestände. Forstliche Forschungsberichte München. Vol. 115. $332 \mathrm{pp}$.

[25] Hasenauer, H. 1994. Ein Einzelbaumwachstumssimulator für ungleichaltrige Fichten- Kiefern- und Buchen-Fichtenmischbestände. Forstlich Schriftenreihe, Univ. f. Bodenkultur, Wien. Vol. 8. 152 pp.

[26] Nord-Larsen, T. and V.K. Johannsen, 2007. A state-space approach to stand growth modelling of European beech. Annals of Forest Science 64, 365-374

[27] Hansen LW, Ravn HP \& Geldmann J. 2005. Within- and between-stand distribution of attacks by pine weevil [Hylobius abietis (L.)], Scandinavian Journal of Forest Research, 20:2, 122-129

[28] Jönsson AM, ·Harding S, Krokene P, Lange H, Lindelöw A, Ø Økland B, Ravn HP, Schroeder LM, 2010. Modelling the potential impact of global warming on Ips typographus voltinism and reproductive diapause. Climatic Change. 2011. 109:695-718

[29] Kroël-Dulay, G; Ransijn, J; Schmidt, IK; Beier, C; De Angelis, P; De Dato, G; Dukes, JS; Emmett, B; Estiarte, M; Garadnai, J; Kongstad, J; Kovács-Láng, E; Larsen, KS; Liberati, D; Ogaya, R; Riis-Nielsen, T; Smith, AR.; Sowerby, A; Tietema, A; Penuelas, J. 2015. Increased sensitivity to climate change in disturbed ecosystems. Nature Communications, Vol. 6, 6682, 2015.

[30] Ransijn J, Damgaard C, Schmidt IK (2015) Do competitive interactions in dry heathlands explain plant abundance patterns and species coexistence? Plant Ecol (2015) 216:199-211

[31] Madsen, C. L., Dahl, C. M., Thirslund, K. B., Grousset, F., Johannsen, V. K. and Ravn, H. P. (2014): Pathways for non-native species in
Denmark. Department of Geosciences and Natural Resource Management, University of Copenhagen, Frederiksberg. $131 \mathrm{pp}$.

[32] deLatil, P. 1956. Thinking by machine. Houghton and Mifflin, Boston. $353 \mathrm{p}$.

[33] Haskell, E. F. 1940. "Mathematical Systematization of 'Environment', 'Organism', and 'Habitat'”, Ecology 21:1-16.

[34] Haskell, E. 1960. 'The Control of Power by Values'. Talk at Men's Class, Riverside Church, New York City, October 25, 1960.

[35] Larsen, J.B. (Ed.) 2005: Naturnær Skovdrift. Dansk Skovbrugs Tidsskrift, 90: 1-400.

[36] Duncker, P. S., K. Raulund-Rasmussen, P. Gundersen, K. Katzensteiner, J. De Jong, H. P. Ravn, M. Smith, O. Eckmüllner, and H. Spiecker. 2012. How forest management affects ecosystem services, including timber production and economic return: synergies and trade-offs. Ecology and Society 17(4): 50.

[37] Sutton M.A., Bleeker A., Howard C.M., Bekunda M., Grizzetti B., de Vries W., van Grinsven H.J.M., Abrol Y.P., Adhya T.K., Billen G.,. Davidson E.A, Datta A., Diaz R., Erisman J.W., Liu X.J., Oenema O., Palm C., Raghuram N., Reis S., Scholz R.W., Sims T., Westhoek H. \& Zhang F.S., with contributions from Ayyappan S., Bouwman A.F., Bustamante M., Fowler D., Galloway J.N., Gavito M.E., Garnier J., Greenwood S., Hellums D.T., Holland M., Hoysall C., Jaramillo V.J., Klimont Z., Ometto J.P., Pathak H., Plocq Fichelet V., Powlson D., Ramakrishna K., Roy A., Sanders K., Sharma C., Singh B., Singh U., Yan X.Y. \& Zhang Y. (2013) Our Nutrient World: The challenge to produce more food and energy with less pollution. Global Overview of Nutrient Management. Centre for Ecology and Hydrology, Edinburgh on behalf of the Global Partnership on Nutrient Management and the International Nitrogen Initiative. $114 \mathrm{p}$.

[38] http://mtewood.com/Forestry/forestry.html

[39] The Zaagkii Project - www.wingsandseeds.org

[40] Ray D; Bathgate S; Moseley D; Taylor P; Nicoll B; Pizzirani S; Gardiner B. 2014. Comparing the provision of ecosystem services in plantation forests under alternative climate change adaptation management options in Wales. Reg Environ Change. DOI $10.1007 /$ s $10113-014-0644-6$

Credits for images in Figure 3:

[41] World population: http://oceanworld.tamu.edu

[42] Book cover: https://en.wikipedia.org/wiki/Capital_in_the_TwentyFirst_Century

[43] Distribution of wealth: http://www.imf.org/external/pubs/ft/fandd/2001/12/wade.htm

[44] B52 bombes: https://en.wikipedia.org/wiki/Boeing_B-52_Stratofortress

[45] Black Rhino extinction http://rebloggy.com/post/nature-humanityconservation-extinct-extinction-rhino-black-rhino-animalconserv/66329677461

[46] Honey bee illustration http://www.inkart.net/illustration/wildlife/western_honey_bee/

[47] Borneo rain forest: http://rainforests.mongabay.com/0801.htm

[48] Microbe characters http://tvtropes.org/pmwiki/pmwiki.php/Toys/GiantMicrobes

[49] Nutrient runoff: http://www.fmr.org/node?page=2 (last image at this url)

[50] Pacific pollution from Fukushima

[51] Smoke stacks: https://texasgreenreport.wordpress.com/tag/air-pollution/

[52] Drought: http://www.conserve-energyfuture.com/GlobalWarmingFacts.php 